\title{
HIV Antibody Measurement
}

National Cancer Institute

\section{Source}

National Cancer Institute. HIV Antibody Measurement. NCI Thesaurus. Code C106527.

A quantitative measurement of the antibody reaction of a biological specimen to the HIV virus. 